Article

\title{
Assessment of Soil and Water Conservation Practices in the Loess Hilly Region Using a Coupled Rainfall-Runoff-Erosion Model
}

\author{
Mengfan Cai ${ }^{1}$, Chunjiang An ${ }^{1, * \mathbb{D}}$, Christophe Guy ${ }^{2}$ and Chen $\mathrm{Lu}^{3}$ \\ 1 Department of Building, Civil and Environmental Engineering, Concordia University, \\ Montreal, QC H3G 1M8, Canada; morvan.cai@outlook.com \\ 2 Department of Chemical and Materials Engineering, Concordia University, Montreal, QC H3G 1M8, Canada; \\ christophe.guy@concordia.ca \\ 3 Institute for Energy, Environment and Sustainable Communities, University of Regina, \\ Regina, SK S4S 0A2, Canada; luchen815@gmail.com \\ * Correspondence: chunjiang.an@concordia.ca
}

Received: 6 January 2020; Accepted: 22 January 2020; Published: 27 January 2020

\begin{abstract}
Soil and water conservation practices (SWCPs) are widely used to control soil and water loss. Quantifying the effect of SWCPs and climate change on soil and water erosion is important for regional environmental management. In this study, the Soil Conservation Service Curve Number (SCS-CN) and the Modified Universal Soil Loss Equation (MUSLE) were employed to investigate the patterns of surface runoff and soil erosion with different SWCPs in the hilly region on the Loess Plateau of China. The impact of climate change under RCP4.5 and RCP8.5 emission scenarios was considered from 2020 to 2050. Surface runoff grew with the increased rainfall and rainfall erosivity, while soil erosion presented large variations between years due to uneven distribution of rainfall and rainfall erosivity under two scenarios. Different SWCPs significantly reduced surface soil and water loss. Compared with bare slopes, the reduction rates were $15-40 \%$ for surface runoff and $35-67 \%$ for soil erosion under RCP4.5 and RCP8.5 emission scenarios, respectively. The combination of shrub and horizontal terracing was recommended due to its low water cost for sediment control among seven SWCPs.
\end{abstract}

Keywords: soil and water conservation practices; soil erosion; surface runoff; water cost for sediment control; MUSLE; SCS-CN; climate change

\section{Introduction}

Soil erosion is a global problem of land degradation which may adversely influence natural and human-affected ecosystems [1]. Around 25-40 billion tons of surface soil and 10 million $\mathrm{hm}^{2}$ of farmland worldwide are eroded annually due to soil erosion, causing a direct economic loss of nearly $\$ 400$ billion USD [2-4]. In particular, approximately five billion tons of topsoil and 67 thousand $\mathrm{hm}^{2}$ of cultivated land are lost each year in China as a result of soil erosion [5]. The Loess Plateau is one of the most important agricultural regions in China, with serious soil erosion [6]. The Grain-to-Green project implemented since 1999 aimed to improve soil conservation in this region. The soil erosion in the Loess Plateau, however, was still higher than $3600 \mathrm{t} \mathrm{km}^{-2} \mathrm{yr}^{-1}$, exceeding the negligible erosion rate of $1000 \mathrm{t} \mathrm{km}^{-2} \mathrm{yr}^{-1}$ [7]. The use of fertilizers in the farmlands with soils prone to erosion risk may affect groundwater and surface water quality. For example, the dissolved reactive phosphorus from fertilizers will transport with surface runoff from farmlands, accelerating eutrophication in receiving water bodies [8]. The release of heavy metals such as $\mathrm{Zn}, \mathrm{Cr}, \mathrm{Cd}, \mathrm{Hg}$, and $\mathrm{Pb}$ from soil erosion may also pose a risk for human health [9]. 
Soil erosion can be affected by some key factors such as climate change, land use, and anthropogenic activities [10-12]. The high-intensity rainfall events have important effects on soil erosion [13]. The mean surface temperature as well as the intensity and frequency of extreme rainfall events will increase during the twenty-first century in the Loess Plateau [14]. Due to climate change, global soil erosion in the next century is expected to increase by approximately $25-50 \%$ [15]. Moreover, soil and water erosion may be influenced by other factors (e.g., soil water content and vegetation cover), which will also be affected by climate change. Field monitoring is easily conducted at small scales (e.g., patches, hillslopes and plots), but it is a challenge to implement over large areas (e.g., watershed and region) considering the required labor and cost [16]. Therefore, evaluations are required to estimate soil erosion at a large scale (e.g., the Loess Plateau) for decision making and regional management considering the future climate change [17]. The Universal Soil Loss Equation (USLE) and its modifications are widely used empirical models for water erosion prediction because they can be applied at large scales with various inputs to consider the future climatic uncertainties [18,19].

Soil and water conservation practices (SWCPs) are one of the most effective measures for erosion control. It can also help adapt to climate change and improve rural development [20]. Over the past 60 years, various SWCPs, including terraces, natural restoration, afforestation, and engineering construction (e.g., check-dams), have been applied in more than 30\% of the Loess Plateau [21]. These practices can significantly reduce soil and water loss and improve environmental quality [22-24]. For example, the use of a permeable reactive barrier filled with materials such as activated carbon and leonardite can intercept the contaminant transport and even transform the contaminant into low or non-toxic substances [25,26]. Liu et al. [27] summarized 53 types of SWCPs used in China. These SWCPs can significantly reduce soil erosion and runoff, but the efficiency of these SWCPs was also affected by the topography, soil characteristics, climatic regime, etc. [28]. Meanwhile, the regional water scarcity in the Yellow River Basin and the conflict between the upper and downstream of the Yellow River in water usage are serious problems. The average runoff may decrease with the increase of vegetation evapotranspiration due to the application of SWCPs [29]. With the growing water scarcity and increasing competition among water users, more efficient water use has increased in importance for sustainable water management and environmental decision-making [30-32]. Therefore, this study aims to develop an approach for the evaluation of SWCPs under future climate scenarios. Improved assessment of SWCPs will be achieved through the use of water cost which can help analyze the balance of soil conservation and runoff reduction, and the incorporation of climate change into soil erosion prediction, which can help understand the performance of SWCPs in a changing environment. Specific goals include evaluating the impact of climate change on soil erosion and surface runoff in a watershed and assessing the water cost for sediment control of seven SWCPs under the future climate scenarios. Climate change, surface runoff, and soil erosion simulated by a coupled rainfall-runoff-erosion model will be investigated to select appropriate SWCPs for the hilly regions on the Loess Plateau. This study regarding the effect of climate change and SWCPs on soil and water loss can be used to support watershed management.

\section{Methodology}

\subsection{Erosion Measurement}

The experimental plots locate at the Dongshan watershed $\left(38^{\circ} 02^{\prime} 20^{\prime \prime}-38^{\circ} 03^{\prime} 48^{\prime \prime} \mathrm{N}\right.$, $111^{\circ} 46^{\prime} 48^{\prime \prime}-111^{\circ} 48^{\prime} 15^{\prime \prime}$ E) of Shanxi Province in China, which is in the southeast of Loess Plateau. This area has a typical semi-arid continental monsoon climate and a fragile ecological environment, with a mean annual rainfall of $500 \mathrm{~mm}(420-540 \mathrm{~mm})$, and a mean air temperature of $9.5^{\circ} \mathrm{C}\left(8.80\right.$ to $\left.10.2^{\circ} \mathrm{C}\right)$. The rainfall is seasonally unsteady, with intensive and short-duration events during the rainy season (June-September), accounting for 75-90\% of total annual rainfall [33]. The average effective evaporation is about $2160 \mathrm{~mm}$ per year, nearly 5 times more than rainfall [34]. Soils in this region are mainly loose and porous loess, containing $64-73 \%$ silt and $17-20 \%$ clay, which are vulnerable to erosive 
activities (e.g., raindrop, runoff, gravity, freeze-thaw, and wind) [33,35]. The watershed, with area around $433 \mathrm{hm}^{2}$ and elevation from 1135 to $1775 \mathrm{~m}$ above sea level, has been affected by human disturbances (e.g., urbanization, deforestation, and mining) and climate change. The reduction of vegetation cover in this region resulted in a gradual increase in soil erosion, flooding and sediment yield. The water-induced erosion models can be modified based on erosion measurements since the soil erosion on the Loess Plateau mainly comes from steep, sparsely vegetated, and highly erosive loess slopes with intensive rainfall and water flow [18,21].

Based on the major SWCPs in the Loess Plateau, eight standard experimental plots with the dimension of $5 \mathrm{~m}$ in width and $20 \mathrm{~m}$ in length each were built to study the impact of SWCPs on soil and water erosion. They were A (Sea-buckthorn + horizontal terracing), B (grass + horizontal terracing), C (forest/Chinese Pine + fish-scale pitting), D (bare slope), E (forest/Arborvitae + fish-scale pitting), F (forest/Arborvitae + horizontal terracing), G (forest/Apricot + horizontal terracing), and $\mathrm{H}$ (forest/Chinese Pine + horizontal terracing). The basic characteristics of these plots are shown in Table 1. These experimental plots were located on the upper and middle positions of the natural semi-shady slope, with a slope of $18^{\circ}$. The soil type at this site was cinnamon soil and the soil thickness was $130 \mathrm{~cm}$. Each plot was bordered with a 35-cm-wide cement wall. A drainage ditch on the upper part and $1.2 \mathrm{~m}$-wide isolation zones on both sides of each plot were designed to prevent the raindrop splashing from the surrounding areas. The lowest part of each plot was built with an outlet $(30 \times 30 \mathrm{~cm})$ linked to the trough, water pipe, and a cement reservoir $(2 \times 1.5 \times 2 \mathrm{~m})$.

Table 1. Basic characteristics of eight experimental plots.

\begin{tabular}{|c|c|c|c|c|c|c|c|c|}
\hline SWCPs $^{1}$ & A & B & $\mathrm{C}$ & D & E & F & G & $\mathbf{H}$ \\
\hline Land use & shrub & grass & forest & bare & forest & forest & forest & forest \\
\hline Vegetation cover (\%) & 71 & 61.7 & 38.5 & 10 & 28.5 & 24.6 & 16.6 & 50.5 \\
\hline P-factor & 0.027 & 0.050 & 0.203 & 1.000 & 0.203 & 0.181 & 0.188 & 0.181 \\
\hline Erosive events & 42 & 34 & 25 & 44 & 38 & 40 & 37 & 39 \\
\hline Duration (min) & 977 & 1078 & 1195 & 1017 & 1054 & 1059 & 1050 & 1053 \\
\hline Intensity $\left(\mathrm{mm} \mathrm{h}^{-1}\right)$ & 2.3 & 2.4 & 2.6 & 2.3 & 2.3 & 2.4 & 2.3 & 2.3 \\
\hline Rainfall (P, mm) & 26.3 & 29.8 & 34.8 & 27.8 & 29.1 & 29.6 & 28.3 & 29.0 \\
\hline Surface runoff (mm) & 1.2 & 1.0 & 1.4 & 1.7 & 1.4 & 1.2 & 1.1 & 1.1 \\
\hline Soil erosion $\left(\mathrm{t} \mathrm{hm}^{-2} \mathrm{yr}^{-1}\right)$ & 7.66 & 8.10 & 20.33 & 29.22 & 18.42 & 16.16 & 19.18 & 11.41 \\
\hline
\end{tabular}

${ }^{1}$ SWCPs: A (Sea-buckthorn + horizontal terracing); B (grass + horizontal terracing); C (forest/Chinese Pine + fish-scale pitting); D (bare slope); E (forest/Arborvitae + fish-scale pitting); F (forest/Arborvitae + horizontal terracing); G (forest/Apricot + horizontal terracing); H (forest/Chinese Pine + horizontal terracing).

The reduction rates of surface runoff $\left(f_{Q}, \%\right)$ and soil erosion $\left(f_{A}, \%\right)$ of different SWCPs were calculated as follows [36]:

$$
\begin{gathered}
f_{Q}=\frac{Q_{0}-Q_{i}}{Q_{0}}, \\
f_{A}=\frac{A_{0}-A_{i}}{A_{0}},
\end{gathered}
$$

where $Q_{0}$ and $A_{0}$ are surface runoff (mm) and soil erosion $\left(\mathrm{t} \mathrm{hm}^{-2} \mathrm{yr}^{-1}\right)$ of the reference plot (D, natural and bare slope), respectively; $Q_{i}$ and $A_{i}$ are surface runoff $(\mathrm{mm})$ and soil erosion $\left(\mathrm{t} \mathrm{hm}^{-2} \mathrm{yr}^{-1}\right)$ of experimental plots with different SWCPs (e.g., grass, fish-scale pitting, horizontal terracing), respectively.

Surface runoff and soil erosion on the slopes can be reduced by SWCPs at the same time, but the reduction effects vary in water and soil erosion among different practices. Water cost for sediment control was proposed by Wang et al. [37] to compare the differences in the decrease of runoff when reducing the same amount of sediment among different practices. It can be calculated by the ratio 
of reduced runoff and soil erosion $\left(R_{r s}, \mathrm{~mm}\left(\mathrm{t} \mathrm{hm}^{-2} \mathrm{yr}^{-1}\right)^{-1}\right)$, which is defined as the ratio of the water-reduced runoff to the reduced soil erosion by SWCPs. The formula was as follows:

$$
R_{r s}=\frac{Q_{d}}{A_{d}}
$$

where $Q_{d}$ and $A_{d}$ are the reduced surface runoff $(\mathrm{mm})$ and soil erosion $\left(\mathrm{t} \mathrm{hm}^{-2} \mathrm{yr}^{-1}\right)$ of each SWCP, respectively. The SWCPs with a small $R_{r s}$ have smaller impact on runoff when reducing the same amount of soil erosion.

\subsection{Rainfall-Runoff-Erosion Model}

\subsubsection{Regional Climate Model}

In this study, climate simulations conducted by regional climate models (RCMs) were used to dynamically downscale climate predictions of global climate models (GCMs) [38]. The RCM system (RegCM4.5) with the hydrostatic core was used in this study, coupled with the Community Land Model (CLM4.5). The microphysics scheme and Emanuel scheme were applied as the moisture scheme and cumulus convective scheme, respectively. This parameterization scheme combination showed satisfying performance in previous studies. For example, Gao et al. [39] found the combination of the Emanuel scheme and CLM3.5 could better simulate the precipitation over China than other scheme combinations. Aerosol processes and atmosphere-ocean coupling, however, were not considered in this study. Besides RCM and scheme options, GCM, scenario, and boundary conditions may cause uncertainties [14]. Ideally, more reliable and consistent climate projections can be produced through a multi-model ensemble [40]. RCM precipitation post-processed by nonparametric transformations could reduce biases and produce reliable estimates of local-scale climate [41]. However, due to the high requirement of computational resources, it is difficult to address all sources of uncertainty and bias. Thus, RegCM and the abovementioned schemes were selected in this study. The area described in the RegCM4.5 is a region of 110 by 135 grid points with a resolution of $50 \mathrm{~km}$ centered at E111 $46^{\prime}$ and $\mathrm{N} 38^{\circ} 3^{\prime}$. To predict the future climate, two Representative Concentration Pathways (RCPs) published by the Inter-governmental Panel on Climate Change (IPCC) were selected to drive the simulation with the highest (RCP8.5: $8.5 \mathrm{~W} / \mathrm{m}^{2}$ by 2100 ) and moderate (RCP4.5: $4.5 \mathrm{~W} / \mathrm{m}^{2}$ by 2100 ) scenarios. The simulations were conducted between 1981 and 2005, with the assumption of accelerated development in the initial five years and exceeding the baseline after 1986. The future climate simulations were run from 2006 to 2050, and the analysis was conducted with the results from 2020 to 2050. The values of monthly rainfall on a $0.5^{\circ}$ grid were available for the hilly Loess Plateau between 2001 and 2050. In this study, climate change scenarios were generated using downscaled average monthly rainfall inputs during 1986-2005. All scenarios were run for 30 years, and rainfall changed during the entire period of 2020-2050. The simulations were presented as annual and monthly averages. The simulated rainfall will provide input to the following models.

\subsubsection{SCS-CN Model}

The Soil Conservation Service curve number (SCS-CN) is an empirical rainfall-runoff model with assumptions and a few inputs to estimate runoff caused by a rainfall event. It is based on the principle of the water balance and two basic assumptions-the proportion of actual runoff to potential maximum runoff is equivalent to the ratio of infiltration to potential maximum interception, and the initial abstraction corresponds to the potential maximum interception. This method was presented as follows [39]:

$$
\begin{gathered}
Q=\left\{\begin{array}{cc}
\frac{(P-\lambda S)^{2}}{P-\lambda S+S} & P>\lambda S \\
0 & P<\lambda S
\end{array},\right. \\
S=254 \times\left(\frac{100}{C N}-1\right),
\end{gathered}
$$


where $P$ is rainfall $(\mathrm{mm}) ; Q$ is surface runoff $(\mathrm{mm}) ; \lambda$ is the initial abstraction rate, which is assumed to be 0.2 in the SCS-CN method. Various values of initial abstraction rate ranging from 0.0 to 0.3 were reported in previous studies, and it was more reasonable for $\lambda$ varying between $0.00-0.05[42,43]$. Combined with the sensitivity analysis conducted in the Loess Plateau by Wang [44], $\lambda=0.00$ was selected for this study. $S$ is the maximum retention $(\mathrm{mm})$, which is directly linked to the curve number (CN). $\mathrm{CN}$ is a dimensionless variable, which can be determined by two methods: (1) using the $\mathrm{CN}$ value-based lookup table based on soil type and land use provided by SCS and (2) calculating the CN value according to the measured data of the experimental plots based on the backward formula from SCS-CN equation $(\lambda=0.00)$ as follows:

$$
C N=\frac{100}{\frac{P}{254} \times\left(\frac{P}{Q}-1\right)+1}
$$

\subsubsection{MULSE Model}

The USLE model was widely applied to predict soil erosion by water forces on the Loess Plateau and it has six important aspects including rainfall erosivity $(R)$, soil erodibility $(K)$, slope length $(L)$, slope gradient $(S)$, crop management $(C)$, and erosion control practice $(P)$ [45]. USLE has some modifications and revisions, mainly including the revised USLE (RUSLE), Chinese Soil Loss Equation (CSLE), and the modified USLE (MUSLE) [19,46,47]. Li et al. [18] compared 11 commonly used soil erosion models on the Loess Plateau and found that empirical models produced sound and quick predictions of soil erosion and sediment yield. On the Loess Plateau, soil erosion was dominated by heavy and intensive rains while low-rainfall events were less important for it. Thus, considering the direct impact of surface runoff on soil erosion, the rainfall-runoff erosivity index $\left(Q_{R} R\right)$, reflecting the erosive force under the combined rainfall and runoff, was introduced into the MUSLE model for Loess Plateau [39]. The runoff-erosion model was formulated as follows:

$$
A=a\left(Q_{R} R\right)^{b} \times K \times L S \times C \times P,
$$

where $A$ is soil erosion $\left(\mathrm{t} \mathrm{hm}^{-2} \mathrm{yr}^{-1}\right)$ on a storm basis; $R$ represents rainfall erosivity factor (MJ mm hm$\left.{ }^{-2} \mathrm{~h}^{-1} \mathrm{yr}^{-1}\right) ; Q_{R}$ is the runoff coefficient (\%), which is the ratio of future runoff and rainfall predicted by the SCS-CN model and the RegCM4 model, respectively; $K$ is the soil erodibility factor $\left(\mathrm{t} \mathrm{hm}^{2} \mathrm{~h} \mathrm{hm}^{-2} \mathrm{MJ}^{-1} \mathrm{~mm}^{-1}\right)$; $L$ is the slope length factor; $S$ stands for the slope factor; $C$ is the dimensionless vegetation cover factor; and $P$ refers to a dimensionless erosion control practice factor. Recommended values for empirical coefficients $a$ and $b$ in this model on the Loess Plateau were 1.723 and 1.548, respectively [39]. The measured data from experimental plots were used to determine the application conditions and model variables for MUSLE.

Rainfall erosivity factor $(R)$ is one of the crucial factors in the MULSE model and it has a direct link with the potential of soil erosion caused by rainfall [48]. Some algorithms of rainfall erosivity have been studied, primarily including classical algorithms and simple algorithms. Wu et al. [49] reviewed $23 R$-factor algorithms and their application scope from 1958 to 2006. The study found that the two simple algorithms - the Wischmeier model and the half-month model—performed better for the hilly Loess Plateau. Although the half-month model was of higher accuracy and more appropriate to be used in the hilly areas, input data for the Wischmeier model were more easily available $[49,50]$. Thus, monthly rainfall $\left(P_{i}\right)$ and annual rainfall $(P)$ were used to estimate the $R$ factor with the Wischmeier model in this study [45]:

$$
R=17.02 \times \sum_{i=1}^{12} 1.735 \times 10^{\left(1.5 \log \left(\frac{P_{i}^{2}}{P}\right)-0.08188\right)},
$$

where $R$ is the annual rainfall erosivity factor $\left(\mathrm{MJ} \mathrm{mm} \mathrm{hm} \mathrm{m} \mathrm{h}^{-1} \mathrm{yr}^{-1}\right) ; P i$ is the average monthly rainfall of $i$-th month from January to December ( $\mathrm{mm}) ; P$ is the annual rainfall $(\mathrm{mm})$. 
Soil erodibility factor $(K)$ is the key parameter to assess the soil susceptibility to erosion, reflecting the soil vulnerability to raindrop splash and runoff flow. The widely used $K$ estimators so far include USLE, the Revised Universal Soil Loss Equation (RUSLE), the Erosion Productivity Impact Calculator (EPIC), and the Geometric Mean Diameter based (Dg) model [51]. These models were developed according to American soil-erosion databases, so they might be ineffective for other regions, e.g., the Loess Plateau. Therefore, Zhang et al. [51] combined several methods for $K$ factor estimation based on the data from the Second Nation Soil Survey (China) and provided the optimally estimated $\mathrm{K}$ factor $\left(K_{\text {opt }}\right)$ combining the revised $K_{\text {nomo }}, K_{\text {epic }}$, and $K_{D g}$ methods. The new estimator performed well in their study and was adopted in the present study as follows:

$$
\begin{gathered}
K_{\text {opt }}=-0.01044+\frac{1.7530}{3}\left[\left(-0.03336+0.7449 K_{\text {nomo }}\right)+\left(-0.01383+0.5158 K_{\text {epic }}\right)+\left(-0.00911+0.5507 K_{D_{g}}\right)\right], \\
K_{\text {nomo }}=0.1317 \times \frac{2.1 \times 10^{-4}(12-S O M) M^{1.14}+3.25(S-2)+2.5(P-3)}{100}, \mathrm{M}=S I L \times(S A N+S I L), \\
K_{\text {epic }}=0.1317 \times\left[0.2+0.3 \exp \left(-0.0256 S A N\left(1-\frac{S I L}{100}\right)\right)\right]\left(\frac{S I L}{C L A+S I L}\right)^{0.3}\left(1.0-\frac{0.25 S O M}{S O M+\exp (3.72-2.95 S O M)}\right) \\
\left(1.0-\frac{0.7 S N 1}{S N 1+\exp (-5.51+22.9 S N 1)}\right), S N 1=1-\frac{S A N}{100}, \\
K_{D g}=7.594\left\{0.0017+0.0494 \exp \left[-0.5\left(\frac{\log (D g)+1.675}{0.6986}\right)^{2}\right]\right\},
\end{gathered}
$$

where SAN, SIL, and CLA are the fraction of sand $(\mathrm{Dg}=0.05-0.1 \mathrm{~mm}, \%)$, silt $(\mathrm{Dg}=0.002-0.05 \mathrm{~mm}$, $\%$ ) and clay ( $\mathrm{Dg}<0.002 \mathrm{~mm}, \%$ ) in the US Soil Texture System, respectively; SOM is the soil organic matter (\%); $S$ is the soil-texture code used in soil classification; $P$ is the profile-permeability class; $D g$ is the geometric mean diameter ( $\mathrm{mm}$ ).

Topographical factors, including slope length factor $(L)$ and slope gradient factor $(S)$, are the factors that directly affect soil erosion. In the original erosion model, slope length is regarded as the horizontal distance from the origin of runoff to the end where soil begins to deposit or runoff starts to concentrate in the defined channel with decreased slope gradient [52]. Rainfall redistribution due to interception and evaporation of vegetation canopies can preserve and reduce surface runoff, so the surface runoff is affected by the specific area and land-use changes along the flow paths [50]. Some calculating methods for the L-factor have been applied in different models at different scales and scopes [18,50,53]. Qin et al. [50] reviewed four $L$-factor calculating methods which were currently widely used for USLE and RUSLE in many countries and proposed a new method to calculate the $L$-factor, considering the comprehensive effect of upslope vegetation coverage and topography on the downslope surface runoff and soil erosion. However, soil erosion increased linearly with the rise of slope length in a uniform slope with limited length [45]. The formulas for $L$-factor and $S$-factor were primarily based on experimental data from natural runoff plots with different slope lengths and slope gradients, respectively, which were as follows [50,54]:

$$
\begin{gathered}
L=\left(\frac{\lambda}{22.13}\right)^{m}, m=\left\{\begin{array}{cc}
0.5 & \theta>5^{\circ} \\
0.4 & 3^{\circ}<\theta \leq 5^{\circ} \\
0.3 & 1^{\circ}<\theta \leq 3^{\circ} \\
0.2 & \theta \leq 1^{\circ}
\end{array},\right. \\
S=\left\{\begin{array}{cc}
21.9 \sin (\theta / 180)-0.96 & \theta \geq 10^{\circ} \\
16.8 \sin (\theta / 180)-0.5 & 5^{\circ} \leq \theta<10^{\circ} \\
10.8 \sin (\theta / 180)+0.03 & \theta<5^{\circ}
\end{array},\right.
\end{gathered}
$$

where $\lambda$ and $\theta$ are the horizontal slope length (m) and the slope gradient $\left(^{\circ}\right)$, respectively; $m$ is a dimensionless empirical coefficient depending on the slope gradient.

Cover management factor $(C)$ refers to the ratio of soil erosion from a slope with and without cover management [45]. This factor can reflect the importance of land cover, crops and crop management 
on soil erosion $[45,55]$. C-factor is closely relevant to vegetation cover which is one sensitive factor influencing soil erosion. Therefore, an equation describing the relationship between $C$-factor and vegetation coverage based on the observations on runoff plots under natural and simulated rainfall was introduced, which was expressed as follows [55]:

$$
C= \begin{cases}1 & f=0 \\ 0.6508-0.3436 \lg f & 0<f \leq 78.3 \% \\ 0 & f>78.3 \%\end{cases}
$$

where $f$ is the vegetation coverage $(\%)$.

Erosion control practice factor $(P)$ is the ratio between soil erosion in a slope with and without one or more specific control practices [45]. These practices will probably change the flow path, direction, and amount of surface runoff, resulting in the reduction of soil erosion [56]. SWCPs in China could be classified into the following three major categories: biological, engineering, and tillage practices [27,47]. By far, contour farming and no-tillage were the most widely applied practices among different tillage options; horizontal terracing was the most frequently used engineering practice; and hedgerow or shrub planting was the most usually tested biological practice $[27,28]$. The efficacy of 15 most frequently tested SWCPs on reducing soil and water erosion was assessed and used to estimate the $P$-factor [28]. If there is no significant control practice, the $P$ factor is regarded as 1 . Based on the above results, the values of the $P$-factor are listed in Table 1.

\subsection{Calibration and Validation}

The calibration and validation method was based on the differences between measured and modelled values. The Nash-Sutcliffe efficiency (NSE) and Root Mean Square Error (RMSE) were adopted to assess the performance of SCN-CN and MUSLE as follows [57]:

$$
\begin{aligned}
& \text { RMSE }=\sqrt{\frac{1}{n} \sum_{i=1}^{n}\left(O_{i}-P_{i}\right)^{2}}, \\
& N S E=1-\frac{\sum_{i=1}^{n}\left(O_{i}-P_{i}\right)^{2}}{\sum_{i=1}^{n}\left(O_{i}-\bar{O}\right)^{2}},
\end{aligned}
$$

where $O_{i}$ is the $i$-th observed value; $P_{i}$ is the $i$-th predicted value; $\bar{O}$ is the average value of the entire observations. RMSE is always positive, and a lower value close to zero means a good fit for the data [58]. NSE ranges from negative infinity to one and the value closer to one denotes a higher model accuracy. NSE $>0.4$ is required for this study as the model performance evaluation standard.

\section{Results and Discussion}

\section{1. $\mathrm{CN}$ and $\mathrm{K}$ in the Rainfall-Runoff-Erosion Model}

Runoff occurs when rainfall is greater than soil absorption or infiltration. Rainfall resulting in surface runoff and soil erosion is called erosive rainfall [59]. The observed rainfall and surface runoff of 44 erosive rainfall events between 2014 and 2017 were used as reference data to calculate the CN of the experimental plots with different SWCPs from January to December (Table 2). The CN values averaged 26.6 among eight plots, varying from 19.2 in plots with Chinese Pine and fish-scale pitting to 38.8 in bare slope. They were generally higher in summers or rainy seasons (May-October) with intensive and frequent rainfalls. These results were consistent with those in some previous studies. Soulis et al. [60] applied the SCS-CN method to analyze the direct runoff generation mechanism in a Mediterranean experimental watershed in Greece and found a strong correlation between the $\mathrm{CN}$ values obtained from measured runoff and the rainfall depth. The proposed two-CN system well 
described the $\mathrm{CN}$-rainfall variation observed in natural watersheds, which could be attributed to the spatial variability of soils and land cover in the watershed [61]. Xiao et al. [62] found $\mathrm{CN}$ values had large differences, ranging from 15 in rangeland to 100 in bare rock land, for various land uses in the Liudaogou watershed, which was also within the hilly region of the Loess Plateau. The bare slope with large $\mathrm{CN}$ value indicated bare slope had more surface runoff and less infiltration [63]. Wang [44] also reported $\mathrm{CN}$ values in the Loess Plateau, varying between $8.81(\lambda=0.00)$ and $75.27(\lambda=0.20)$, which was closely related to the selected initial abstraction rate. The model with $\lambda=0.00$ had the smallest $\mathrm{CN}$ value and the largest potential maximum interception (S) in the watershed because this revision ignored the initial abstraction before runoff and the antecedent soil moisture content.

Table 2. Curve number $(\mathrm{CN})$ value of experimental plots with different soil and water conservation practices (SWCPs) from January to December.

\begin{tabular}{ccccccccc}
\hline SWCPs & A & B & C & D & E & F & G & H \\
\hline 1 & 26.8 & 21.9 & 15.7 & 38.3 & 16.1 & 7.5 & 22.9 & 29.3 \\
2 & 26.8 & 21.9 & 15.7 & 38.3 & 16.1 & 7.5 & 22.9 & 29.3 \\
3 & 26.8 & 21.9 & 15.7 & 38.3 & 16.1 & 7.5 & 22.9 & 29.3 \\
4 & 26.8 & 21.9 & 15.7 & 38.3 & 16.1 & 7.5 & 22.9 & 29.3 \\
5 & 26.8 & 21.9 & 15.7 & 38.3 & 16.1 & 7.5 & 22.9 & 29.3 \\
6 & 39.0 & 29.1 & 10.6 & 28.9 & 23.5 & 24.2 & 22.2 & 13.3 \\
7 & 22.2 & 19.8 & 22.3 & 30.8 & 26.7 & 25.2 & 17.4 & 22.3 \\
8 & 26.8 & 20.3 & 23.2 & 28.6 & 22.8 & 18.3 & 23.6 & 23.9 \\
9 & 35.4 & 17.9 & 34.4 & 31.6 & 20.4 & 20.5 & 23.5 & 25.7 \\
10 & 26.8 & 29.4 & 20.6 & 51.2 & 38.7 & 38.8 & 45.1 & 41.8 \\
11 & 26.8 & 29.4 & 20.6 & 51.2 & 38.7 & 38.8 & 45.1 & 41.8 \\
12 & 26.8 & 29.4 & 20.6 & 51.2 & 38.7 & 38.8 & 45.1 & 41.8 \\
Average & 28.9 & 23.7 & 19.2 & 38.8 & 24.2 & 20.2 & 28.0 & 29.8 \\
\hline
\end{tabular}

Table 3 shows the values of soil erodibility factor $\left(K_{o p t}, \mathrm{thm}^{2} \mathrm{~h} \mathrm{hm}^{-2} \mathrm{MJ}^{-1} \mathrm{~mm}^{-1}\right)$ of experimental plots with different SWCPs, varying between 0.001 in plot B and 0.012 in Plot E. In previous studies, Zhang et al. [64] calculated a set of erodibility values for main soils on the Loess Plateau based on the data from several field stations and found that the $K$-factor for loess soils varied from 0.3 to 0.6 in the American system and from 0.008 to 0.04 in the metric system. Zhang et al. [51] also proposed a linear combination of the revised $K_{\text {epic }}$ and $K_{D g}$ methods for soil erodibility estimation based on the data from the Second Nation Soil Survey and the $K$ value of $0.0163 \mathrm{t} \mathrm{hm}^{2} \mathrm{~h} \mathrm{hm}^{-2} \mathrm{MJ}^{-1} \mathrm{~mm}^{-1}$ was obtained for loessial soils with slope gradient of $9 \%$. Wang et al. [65] reported that previous equations overestimated most of the $K$-factor and the $K_{D g}$, and $K_{\text {nomo }}$ could be the only reliable method to be applied directly to the Loess Plateau. The mean $K$ values were $0.0321 \mathrm{t} \mathrm{hm}^{2} \mathrm{~h} \mathrm{hm}^{-2} \mathrm{MJ}^{-1} \mathrm{~mm}^{-1}$ in Chinese water erosion regions and 0.0384 in Shanxi, which were close to the values of $K_{D g}(0.0411)$ and $K_{\text {nomo }}(0.0451)$ but lower than $K_{\text {epic }}$ values of $0.053 \mathrm{t} \mathrm{hm}^{2} \mathrm{~h} \mathrm{hm}^{-2} \mathrm{MJ}^{-1} \mathrm{~mm}^{-1}$ in this study. Soil characteristics, such as soil texture and SOM, had significant impacts on soil erodibility $[51,66]$. The soil in this study area had low SOM with an average of $1.01 \%$, thus, the values of soil erodibility factor could be overestimated for these plots when $K_{\text {epic }}$ estimator was adopted to estimate $K$-factor. 
Table 3. Soil erodibility factor $\left(\mathrm{K}, \mathrm{t} \mathrm{hm}^{2} \mathrm{~h} \mathrm{hm}^{-2} \mathrm{MJ}^{-1} \mathrm{~mm}^{-1}\right)$ of experimental plots with different SWCPs.

\begin{tabular}{ccccccccc}
\hline SWCPs & A & B & C & D & E & F & G & H \\
\hline SAN (\%) & 20.4 & 19.2 & 24.3 & 15.3 & 13.5 & 17.1 & 22.1 & 17.9 \\
SIL (\%) & 53.7 & 52.7 & 52 & 58.7 & 65.7 & 59.1 & 56.1 & 58.5 \\
CLA (\%) & 27.3 & 20.2 & 9.1 & 16.8 & 17.8 & 16.9 & 10.9 & 18.3 \\
SOM (\%) & 0.9 & 0.8 & 0.65 & 1.2 & 1.1 & 1.16 & 0.99 & 1.24 \\
Dg (mm) & 0.9 & 1.1 & 0.7 & 0.8 & 0.7 & 0.8 & 0.9 & 0.8 \\
p & 2 & 3 & 4 & 2 & 2 & 2 & 3 & 2 \\
s & 3 & 3 & 3 & 3 & 3 & 3 & 3 & 3 \\
$K_{\text {nomo }}$ & 0.040 & 0.041 & 0.047 & 0.043 & 0.053 & 0.045 & 0.047 & 0.044 \\
K $_{\text {epic }}$ & 0.052 & 0.054 & 0.054 & 0.054 & 0.056 & 0.053 & 0.053 & 0.052 \\
K $_{\text {Dg }}$ & 0.038 & 0.031 & 0.048 & 0.042 & 0.048 & 0.042 & 0.038 & 0.042 \\
$\mathrm{~K}_{\text {opt }}$ & 0.002 & 0.001 & 0.009 & 0.005 & 0.012 & 0.006 & 0.006 & 0.005 \\
\hline
\end{tabular}

\subsection{Observed and Predicted Soil and Water Erosion}

The calibration and validation results for the surface runoff and soil erosion are presented in Table 4 . The minimum RMSE between the observed $\left(O_{i}\right)$ and predicted $\left(P_{i}\right)$ soil erosion was achieved with the empirical coefficients ( $a$ and $b$ ) of SWCPs in the range of 1.609-3.409 and 1.150-1.631, respectively. The modeling performance of MULSE for soil erosion and SCS-CN for the surface runoff was good, and the NSE values showed a positive efficiency for all experimental plots (NSE $>0.4$ ). The surface runoff was overestimated for the majority of severe runoff events on all experimental plots, and soil erosion was underestimated for smaller runoff values and overestimated for heavy erosive events. Model parameters and input data may lead to uncertainty in the simulation process. Slope gradient, antecedent soil moisture, and rainfall intensity are crucial factors to predict surface runoff and soil erosion [67]. In this study, only monthly rainfall was used as climatic input to the model. Rainfall intensity and rainfall duration greatly influenced the amount of runoff, but they were not included in this SCS-CN model [68]. The rainfall erosivity calculated using the Wischmeier model based on monthly rainfall was higher than that calculated using a half-month model based on daily rainfall. That could be attributed to a certain degree of deviation between high intensity and short duration rainfall [49], which overestimated the soil erosion especially for heavy erosive events. Consequently, the MUSLE model may overestimate the total soil erosion from eight experimental plots in this study. Notably, the gravitational soil erosion was not considered in the MUSLE model of this study because water-induced erosion was dominating in this area. 
Table 4. Root mean square error (RMSE) and Nash-Sutcliffe efficiency (NSE) of observed and predicted surface runoff (Q, mm) and soil erosion (A, thm ${ }^{-2} \mathrm{yr}^{-1}$ ) from experimental plots with different SWCPs.

\begin{tabular}{|c|c|c|c|c|c|c|c|c|c|c|c|c|c|c|c|c|c|c|}
\hline \multirow{3}{*}{ SWCPs } & \multirow{2}{*}{\multicolumn{2}{|c|}{ MULSE }} & \multicolumn{8}{|c|}{ Calibration } & \multicolumn{8}{|c|}{ Validation } \\
\hline & & & \multicolumn{4}{|c|}{$\mathbf{Q}$} & \multicolumn{4}{|c|}{ A } & \multicolumn{4}{|c|}{$\mathbf{Q}$} & \multicolumn{4}{|c|}{$\mathbf{A}$} \\
\hline & a & b & Observed & Predicted & RMSE & NSE & Observed & Predicted & RMSE & NSE & Observed & Predicted & RMSE & NSE & Observed & Predicted & RMSE & NSE \\
\hline A & 3.109 & 1.621 & 1.38 & 1.35 & 0.65 & 0.72 & 4.28 & 3.52 & 5.04 & 0.54 & 1.01 & 1.21 & 0.66 & 0.65 & 9.97 & 10.75 & 8.31 & 0.65 \\
\hline B & 3.409 & 1.631 & 0.82 & 0.84 & 0.28 & 0.81 & 2.04 & 1.55 & 1.59 & 0.93 & 1.14 & 1.44 & 0.82 & 0.58 & 11.86 & 12.24 & 8.39 & 0.46 \\
\hline C & 2.849 & 1.231 & 1.33 & 1.21 & 0.66 & 0.58 & 11.5 & 8.66 & 6.6 & 0.75 & 1.38 & 1.94 & 0.87 & 0.58 & 28.48 & 27.42 & 8.05 & 0.88 \\
\hline D & 1.681 & 1.15 & 1.6 & 1.76 & 0.47 & 0.92 & 15.9 & 15.86 & 19.51 & 0.53 & 1.72 & 2.15 & 1.11 & 0.74 & 38.44 & 46.43 & 14.53 & 0.89 \\
\hline E & 1.609 & 1.233 & 1.19 & 1.26 & 0.65 & 0.82 & 6.67 & 6.83 & 6.71 & 0.73 & 1.54 & 1.74 & 0.88 & 0.76 & 25.28 & 24.3 & 15.44 & 0.57 \\
\hline F & 3.023 & 1.288 & 1 & 1.18 & 0.49 & 0.83 & 7.44 & 7.54 & 7.22 & 0.65 & 1.34 & 1.54 & 0.97 & 0.67 & 21.4 & 26.98 & 14.56 & 0.7 \\
\hline G & 2.509 & 1.319 & 0.96 & 1.15 & 0.4 & 0.74 & 11.7 & 7.54 & 10.73 & 0.54 & 1.16 & 1.42 & 1.11 & 0.43 & 22.34 & 28.5 & 19.51 & 0.43 \\
\hline $\mathbf{H}$ & 2.559 & 1.258 & 1.01 & 1.15 & 0.48 & 0.83 & 4.68 & 4.27 & 4.6 & 0.72 & 1.18 & 1.64 & 1.12 & 0.41 & 15.61 & 15.15 & 12.8 & 0.48 \\
\hline Average & & & 1.18 & 1.26 & 0.53 & 0.81 & 8.06 & 7.18 & 9.71 & 0.59 & 1.31 & 1.62 & 1.00 & 0.63 & 21.55 & 24.19 & 14.3 & 0.72 \\
\hline
\end{tabular}




\subsection{Impact of Climate Change on Soil and Water Erosion}

The impact of climate change on soil and water erosion is shown in Figure 1 in terms of the relative difference in rainfall, rainfall erosivity factor, surface runoff, and soil erosion between the historical climate (1986-2005) and the two RCP scenarios (RCP4.5 and RCP8.5) during 2020-2050. Projections by RegCM4 showed that the annual average rainfall for the two scenarios during that period were 909.6 and $922.6 \mathrm{~mm}$, respectively, with an increase of $16 \%$ and $18 \%$ compared to historical climate $(785.0 \mathrm{~mm})$, respectively. The result was consistent with the previous studies. Yellow River Basin would be likely to experience rainfall increase in the projected scenarios [14]. Compared with historical climate (1950-1999), GCMs projected a $4-18 \%$ and $23-37 \%$ increase in annual rainfall for the region during 2010-2039 and 2070-2099, respectively [69]. Rainfall erosivity is influenced by the amount, intensity, and duration of rainfall. Its temporal distributions have a strong relationship with the erosive rainfall. Generally, more rainfall can cause larger rainfall erosivity [49]. The annual averages of the rainfall erosivity for RCP4.5 and RCP8.5 in the years of 2020-2050 were 20,518.72 and $20,606.60 \mathrm{MJ} \mathrm{mm} \mathrm{hm}{ }^{-2} \mathrm{~h}^{-1} \mathrm{yr}^{-1}$, respectively, with a slight increase of $1 \%$ and $7 \%$ compared to

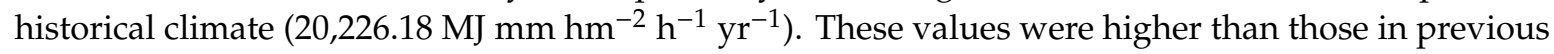
studies probably because the impact of high intensity and short duration rainfall on the Wischmeier model was greater than that on the half-month model [49]. Annual surface runoff for RCP4.5 and RCP8.5 emission scenarios showed a similar average, approximately $141 \mathrm{~mm}$, during the period 2020-2050, which was $28 \%$ higher than that of the historical climate. However, annual soil erosion was projected with the changes in the range of $-96 \%$ to $235 \%$ and $-92 \%$ to $448 \%$ for the two scenarios compared to the historical climate, respectively. The large variations with years might be due to the large intra-annual variability of rainfall and rainfall erosivity. For example, the rainfall depth (around $725 \mathrm{~mm}$ ) was approximately equal for 2040, 2048, and 2050 under RCP8.5 scenario, but the rainfall erosivity and soil erosion in 2040 were over twice as much as the others. This was because heavy rainfalls were more concentrated in rainy seasons and $57 \%, 40 \%$, and $31 \%$ of total rainfall depth occurred in July and August in 2040, 2048, and 2050, respectively. The surface runoff and soil erosion in the rainy season (May-October) under future scenarios accounted for nearly $90 \%$ and $99 \%$ of the total amount in a year, respectively. This was consistent with the results of Azari et al. [70] that nearly $75 \%$ of the soil erosion occurred in the rainy season because of heavy rainfall. The frequency and intensity of large storms may increase rainfall erosivity force and cause more surface runoff and soil erosion $[69,70]$. Water-induced soil erosion mainly resulted from soil particle detachment by the shearing force of raindrops and overland flow, and the movement and transport by rain splash and runoff [71]. Surface runoff and soil erosion generally increased with rainfall, but many other factors such as antecedent rainfall and vegetation coverage also affected them [72]. Antecedent rainfall had a strong impact on the generation of surface runoff and soil erosion on slopes during rainfall events. Surface runoff and soil erosion on slopes with large antecedent rainfall may be higher than that without antecedent rainfall because the antecedent rainfall could recharge and saturate surface fractures which usually reduce surface runoff. Saturation excess runoff generally occurred when the rainfall intensity was higher than soil infiltration rates [73]. Therefore, more heavy rainfall and runoff events in the rainy season will result in more soil and water erosion. However, climate change may contribute to $14.3-31 \%$ of streamflow change in north China [74,75], while human activities, such as land-use change and SWCPs, would also be an important factor influencing runoff and soil erosion [68,76].

\subsection{The Effect of Different SWCPS on Soil and Water Conservaion}

Seven SWCPs and a bare slope without any SWCPs were studied using SCS-CN and MULSE with RCP4.5 and RCP8.5 during 2020-2050 to quantify the effect of different SWCPs on soil and water erosion under future climate change. The predicted surface runoff and soil erosion of experimental plots are presented in Figure 2. The results showed the reduction rates of $15-40 \%$ for surface runoff and $35-67 \%$ for soil erosion under RCP4.5 and RCP8.5 scenarios during 2020-2050, respectively. This means that SWCPs performed well for the slopes in terms of soil and water conservation. Previous studies 
also reported that more than $90 \%$ of the erosion resulted from the bare slopes without vegetation cover, which was significantly higher than that on the slopes with vegetation cover [7,77]. Compared with historical climate, under traditional tillage, the WEPP model (Watershed Erosion Prediction Project) predicted a change of $49-112 \%$ and $29-79 \%$ for runoff, $31-167 \%$ and $2-81 \%$ for soil erosion during 2010-2039 and 2070-2099, respectively [78,79]. However, conservation farming produced low runoff and soil erosion. Therefore, it could reduce the adverse effect of future climate changes on agro-ecosystems. Compared to traditional farming under the historical climate, conservation farming could reduce runoff by $-34-71 \%$ and $18-38 \%$ and decrease soil erosion by $26-77 \%$ and $56-68 \%$ during 2010-2039 and 2070-2099, respectively [69,78]. Moreover, the reduction rates of soil erosion by different SWCPs were mostly higher than those of surface runoff because surface runoff was simulated by the SCS-CN method which was closely related to rainfall. The response of soil erosion was nonlinear with rainfall and was estimated by MULSE, which was affected by rainfall amount and intensity, the soil moisture content in the early stage, soil physical properties, SWCPs, land use, and vegetation coverage [77].

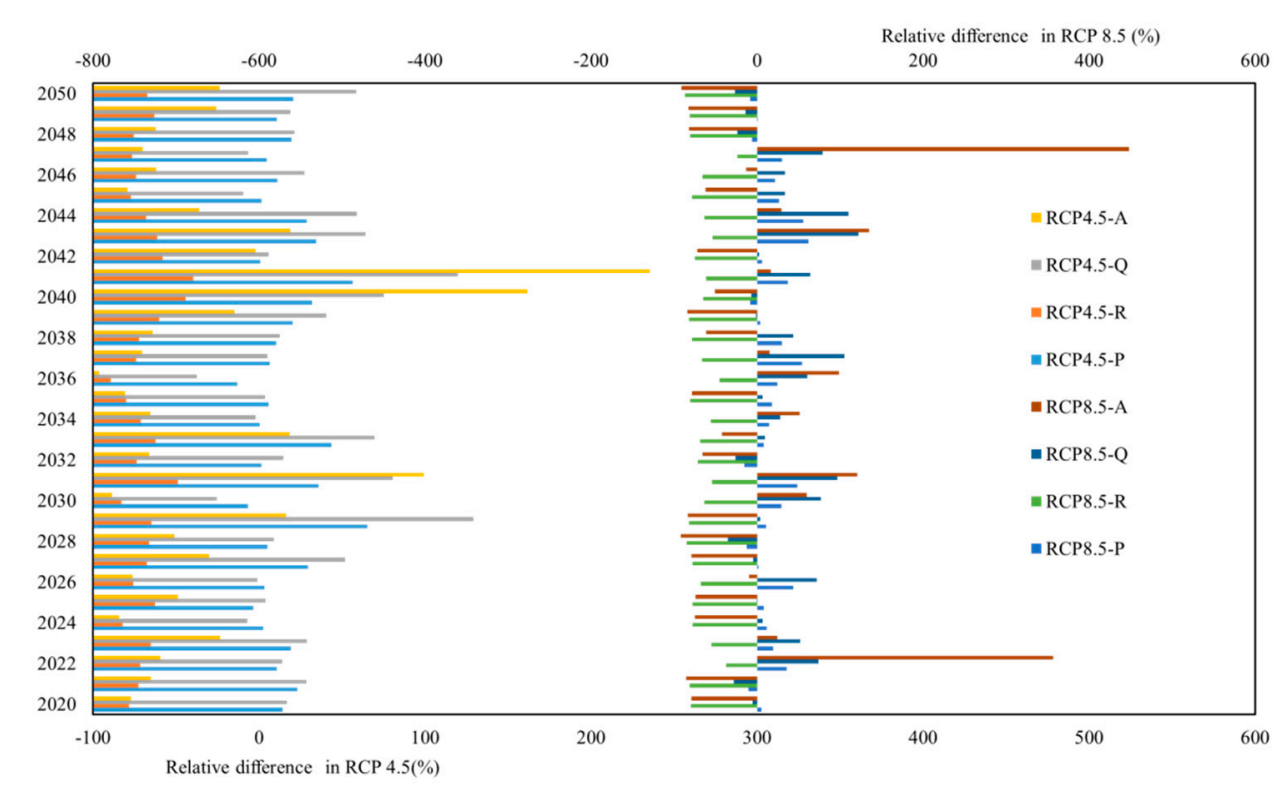

Figure 1. Relative differences in rainfall (P), rainfall erosivity factor $(\mathrm{R})$, surface runoff $(\mathrm{Q})$, and soil erosion (A) between the historical climate (1986-2005) and the two RCP scenarios (RCP4.5 and RCP8.5) during 2020-2050.

The reduction rates of surface runoff and soil erosion varied among experimental plots with different SWCPs (Figure 2). These SWCPs could reduce surface runoff and soil erosion because the topography of the watershed could be changed to greatly delay surface runoff, improve rainfall infiltration, and reduce the runoff discharge. A large proportion of rainfall can be retained by vegetation and evaporate into the atmosphere, causing a significant decrease in the effective rainfall for runoff generation [68]. Under the same rainfall conditions, plot A (shrub/Seabuckthorn + horizontal terracing), $\mathrm{B}$ (grass + horizontal terracing), and $\mathrm{H}$ (forest/Chinese Pine + horizontal terracing) showed high reduction rates of soil erosion (about 54,68, and 67\%, respectively), which were due to the high vegetation cover (50.5-71.0\%). It can be seen that plot A showed a lower reduction effect (about 15\%) on surface runoff than other plots, which was probably because a part of retained rainfall by shrubs flew down the trunks or dropped from leaves to the surface quickly and produced secondary surface runoff and soil erosion. Previous studies have shown that ecological factors (e.g., tree canopy, shrub and grass coverage, litter depth, and woody debris) may affect the surface runoff and soil erosion. Specifically, the size and erosive power of raindrops were influenced by tree canopy. Ground cover, such as short shrub, grass, woody debris, and litter cover, offered a rough surface that reduced soil particle detachment, 
movement, and transport down the slope $[72,80]$. Therefore, stemflow and throughfall from tall forest may cause more secondary soil erosion than short shrubs because of strong erosive power of raindrops and less ground cover in this study.
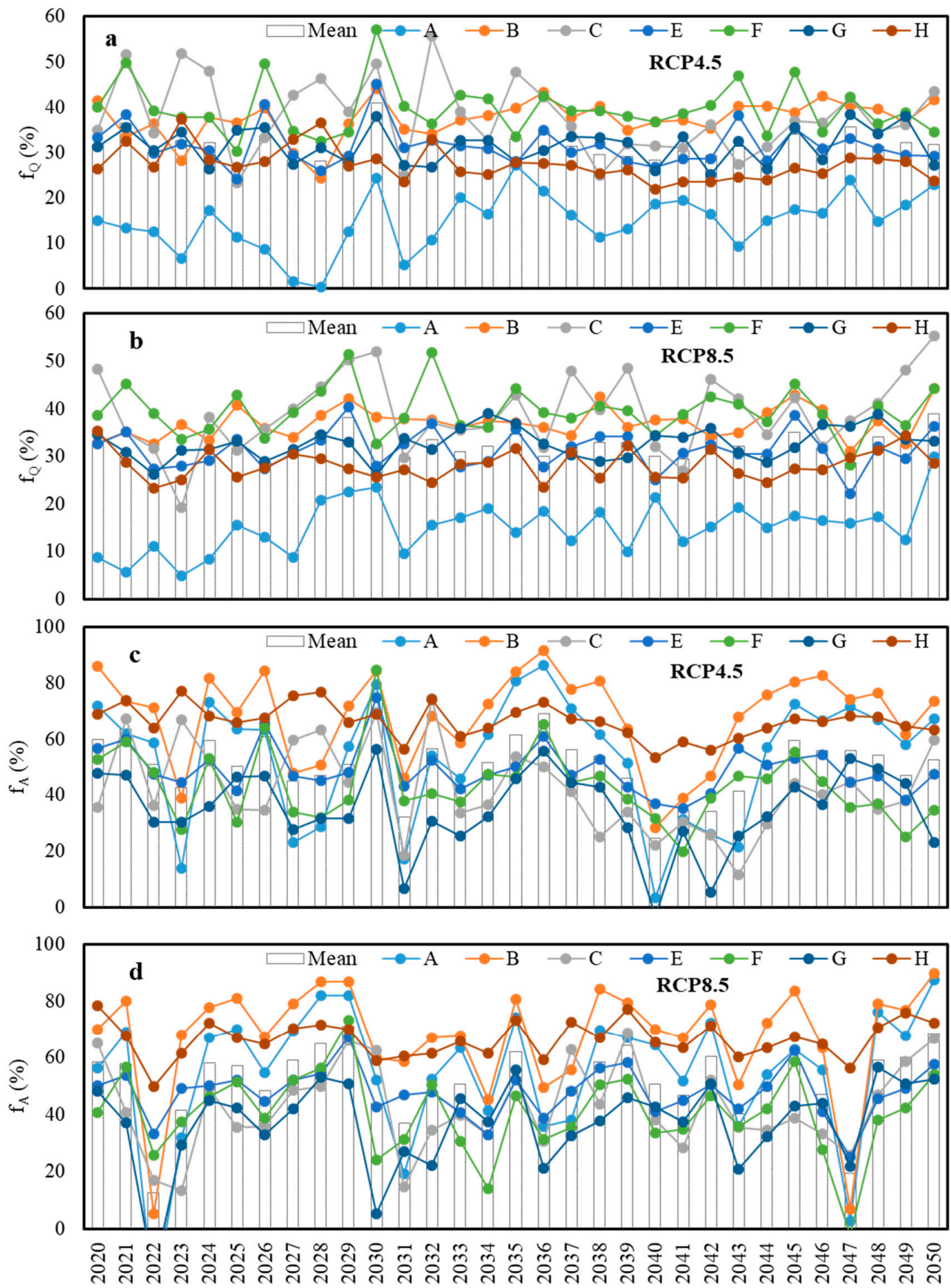

Figure 2. The reduction rates of different SWCPs for two scenarios (RCP4.5 and RCP8.5) during the period of 2020-2050: (a) surface runoff $\left(f_{Q}, \%\right)$ under RCP4.5 scenario; $(b)$ surface runoff $\left(f_{Q}, \%\right)$ under RCP8.5 scenario; (c) soil erosion $\left(f_{A}, \%\right)$ under RCP4.5 scenario; $(d)$ soil erosion $\left(f_{A}, \%\right)$ under RCP8.5 scenario.

Water costs for sediment control $\left(R_{r s}, \mathrm{~mm}\left(\mathrm{t} \mathrm{hm}^{-2} \mathrm{yr}^{-1}\right)^{-1}\right)$ of seven SWCPs under two scenarios (RCP4.5 and RCP8.5) during the period 2020-2050 are presented in Figure 3. The results showed that $R_{r s}$ was in the range of 0.35-3.13 and 0.34-1.90 under RCP4.5 and RCP8.5 scenarios during 2020-2050, respectively. When reducing the soil erosion by similar quantities, plot $\mathrm{A}$ with the lowest $R_{r s}$, nearly 
$0.41 \mathrm{~mm}\left(\mathrm{t} \mathrm{hm}^{-2} \mathrm{yr}^{-1}\right)^{-1}$, had smaller impacts on runoff, while plot $\mathrm{C}$ (forest/Chinese Pine + fish-scale pitting) with the largest $R_{r s}$ of $1.29 \mathrm{~mm}\left(\mathrm{t} \mathrm{hm}^{-2} \mathrm{yr}^{-1}\right)^{-1}$ reduced larger runoff compared to other SWCPs. Considering the $R_{r s}$ of individual SWCPs in the hilly loess region, Yan [81] showed that the $R_{r s}$ slightly varied among different SWCPs, with the order: shrub > deciduous broadleaved forest $>$ evergreen coniferous forest $>$ fish-scale pitting $>$ horizontal terracing $>$ grass. It suggested that the combination of forest and fish-scale pitting could result in a higher $R_{r s}$ than a single SWCP, while horizontal terracing would reduce $R_{r s}$ when combined with shrub because $R_{r s}$ simultaneously decreased with the increase of rainfall, runoff, and soil erosion [82].
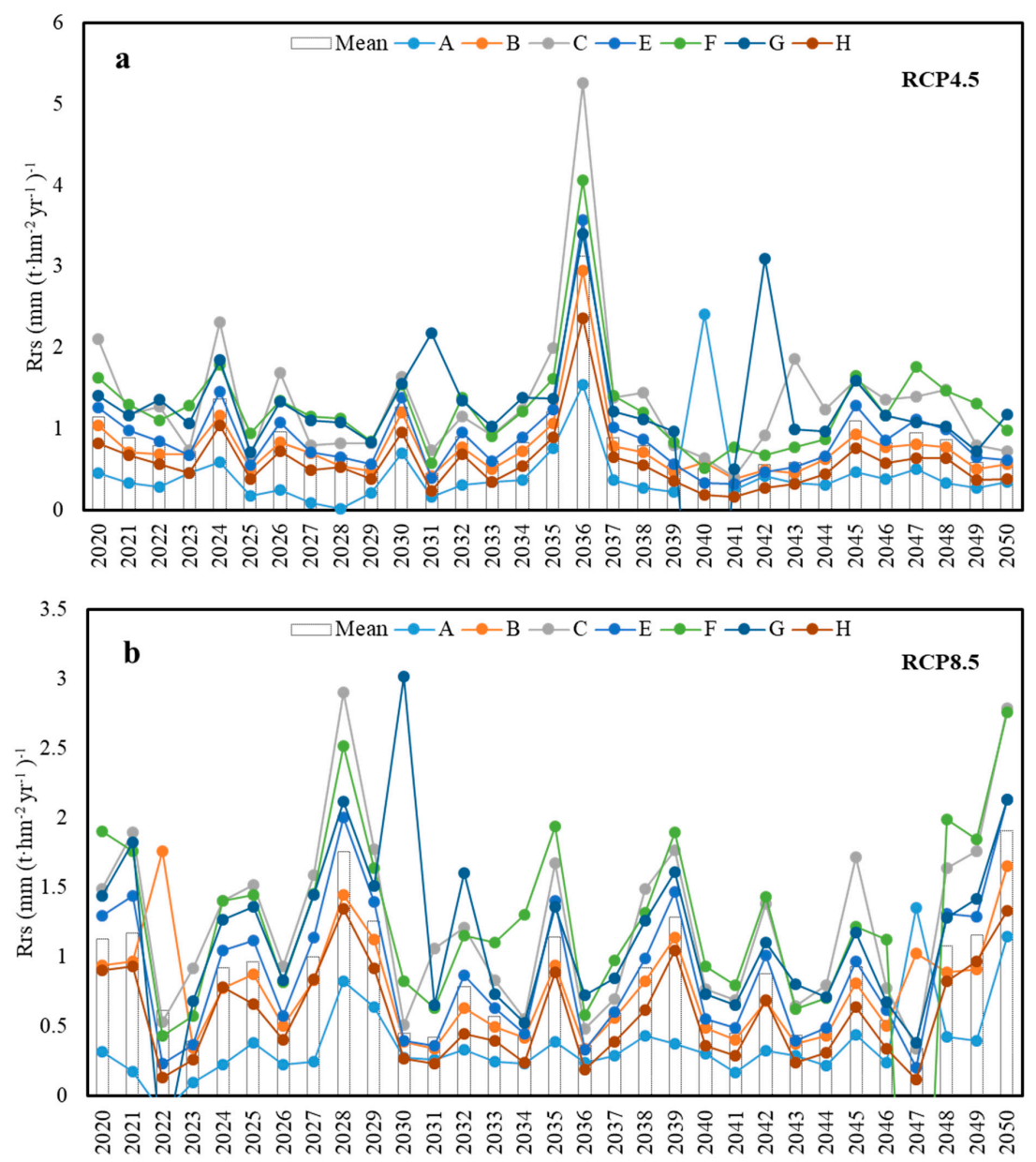

Figure 3. Water cost for sediment control $\left(R_{r s}, \mathrm{~mm}\left(\mathrm{t} \mathrm{hm}^{-2} \mathrm{yr}^{-1}\right)^{-1}\right)$ of different SWCPs during the period of 2020-2050: (a) $R_{r s}$ under RCP4.5 scenario; (b) $R_{r s}$ under RCP8.5 scenario.

\section{Conclusions and Recommendations}

SWCPs have obvious effects on reducing soil and water loss. The results of this study showed that surface runoff and soil erosion were closely related to rainfall depth, rainfall intensity, and rainfall erosivity. Surface runoff showed a $28 \%$ increase compared to historical climate, while soil erosion presented large variations with years due to uneven distribution of rainfall and rainfall erosivity in a year. Compared with bare slopes, the reduction rates were $15-40 \%$ for surface runoff and $35-67 \%$ for soil erosion under RCP4.5 and RCP8.5 scenarios during 2020-2050, respectively. When reducing the soil erosion by similar quantities, the combination of shrub and horizontal terracing had smaller impacts on runoff compared to other SWCPs. Growing vegetation captured eroded sediment from the upper part of the slopes. Moreover, vegetation growth stabilized the slope, which decreased gravitational erosion [71]. In the long run, vegetation can help decrease surface runoff and soil erosion to a safe level through improving soil chemical-physical properties and anti-erodibility [30]. However, 
compared to engineering practices, the effect of biological practices on soil erosion conservation might be postponed because vegetation like trees, shrubs, and grass require a long period to adapt to the changes in soil features, topography, and local climate [17]. Therefore, the combination of shrub and horizontal terracing is the desired recommendation for controlling surface runoff and soil erosion because this combination has smaller impacts on runoff when reducing the soil erosion by similar quantities. The results of this study can be used to assess soil and water erosion, support small watershed management, and preserve the ecosystem of erosive areas.

Author Contributions: These authors contributed equally to this work. Their individual contributions were as follows: conceptualization, M.C. and C.A.; methodology, M.C. and C.A.; software, M.C. and C.L.; validation, M.C.; formal analysis, M.C.; investigation, M.C.; resources, M.C. and C.L.; writing-original draft preparation, M.C.; writing-review and editing, M.C., C.A. and C.G.; supervision, C.A. and C.G. All authors have read and agreed to the published version of the manuscript.

Funding: This research was supported by the Natural Sciences and Engineering Research Council of Canada.

Acknowledgments: The authors are grateful to the editor and the anonymous reviewers for their insightful comments and suggestions.

Conflicts of Interest: The authors declare no conflict of interest.

\section{References}

1. Lal, R. Soil erosion and the global carbon budget. Environ. Int. 2003, 29, 437-450. [CrossRef]

2. Pennock, D.; McKenzie, N.; Montanarella, L. Status of the world's soil resources; FAO Rome: Rome, Italy, 2015.

3. Montanarella, L. Agricultural policy: govern our soils. Nat. News 2015, 528, 32. [CrossRef] [PubMed]

4. Pimentel, D.; Burgess, M. Soil erosion threatens food production. Agriculture 2013, 3, 443-463. [CrossRef]

5. MWR of PRC. The proclamation of soil and water loss in China; MWR: Beijing, China, 2002.

6. Wang, Y.; Gao, X.; Li, T.; Yue, Y.; Fang, H.; Ni, J. Geocode-based aquatic habitats in hierarchical system of the Yellow River Basin. J. Environ. Inform. 2018, 32, 69-81. [CrossRef]

7. Fu, B.; Liu, Y.; Lü, Y.; He, C.; Zeng, Y.; Wu, B. Assessing the soil erosion control service of ecosystems change in the Loess Plateau of China. Ecol. Complex. 2011, 8, 284-293. [CrossRef]

8. Wang, Z.; Zhang, T.; Tan, C.; Wang, X.; Taylor, R.; Qi, Z.; Yang, J. Modeling the impacts of manure on phosphorus loss in surface runoff and subsurface drainage. J. Environ. Qual. 2019, 48, 39-46. [CrossRef]

9. Sawut, R.; Kasim, N.; Maihemuti, B.; Hu, L.; Abliz, A.; Abdujappar, A.; Kurban, M. Pollution characteristics and health risk assessment of heavy metals in the vegetable bases of northwest China. Sci. Total Environ. 2018, 642, 864-878. [CrossRef]

10. Zhang, P.; Huang, G.; An, C.; Fu, H.; Gao, P.; Yao, Y.; Chen, X. An integrated gravity-driven ecological bed for wastewater treatment in subtropical regions: Process design, performance analysis, and greenhouse gas emissions assessment. J. Clean. Prod. 2019, 212, 1143-1153. [CrossRef]

11. Colman, C.B.; Oliveira, P.T.S.; Almagro, A.; Soares-Filho, B.S.; Rodrigues, D.B. Effects of climate and land-cover changes on soil erosion in Brazilian pantanal. Sustainability 2019, 11, 7053. [CrossRef]

12. Xu, Q.; Chen, Q.; Zhao, S.; Liu, K.; Ma, J. Saving water and associated energy from distribution networks by considering landscape factors in pressure management and use of district metered areas. J. Environ. Inform. 2018, 31, 65-73. [CrossRef]

13. Routschek, A.; Schmidt, J.; Kreienkamp, F. Impact of climate change on soil erosion—a high-resolution projection on catchment scale until 2100 in Saxony/Germany. Catena 2014, 121, 99-109. [CrossRef]

14. Lu, C.; Huang, G.; Wang, X. Projected changes in temperature, precipitation, and their extremes over China through the RegCM. Clim. Dyn. 2019, 53, 5859-5880. [CrossRef]

15. Delgado, J.A.; Nearing, M.A.; Rice, C.W. Conservation practices for climate change adaptation. In Advances in Agronomy; Elsevier: Amsterdam, The Netherlands, 2013; Volume 121, pp. 47-115.

16. Fu, B.; Li, S.; Yu, X.; Yang, P.; Yu, G.; Feng, R.; Zhuang, X. Chinese ecosystem research network: progress and perspectives. Ecol. Complex. 2010, 7, 225-233. [CrossRef]

17. Millington, J.D.; Wainwright, J.; Mulligan, M. Representing human decision-making in environmental modelling. Environ. Model. 2013, 291. 
18. Li, P.; Mu, X.; Holden, J.; Wu, Y.; Irvine, B.; Wang, F.; Gao, P.; Zhao, G.; Sun, W. Comparison of soil erosion models used to study the Chinese Loess Plateau. Earth-Sci. Rev. 2017, 170, 17-30. [CrossRef]

19. Sadeghi, S.; Gholami, L.; Khaledi Darvishan, A.; Saeidi, P. A review of the application of the MUSLE model worldwide. Hydrol. Sci. J. 2014, 59, 365-375. [CrossRef]

20. Abdul-Rahim, A.; Sun, C.; Noraida, A. The impact of soil and water conservation on agricultural economic growth and rural poverty reduction in China. Sustainability 2018, 10, 4444. [CrossRef]

21. Zhao, G.; Mu, X.; Wen, Z.; Wang, F.; Gao, P. Soil erosion, conservation, and eco-environment changes in the Loess Plateau of China. Land Degrad. Dev. 2013, 24, 499-510. [CrossRef]

22. Cai, M.; Xin, Z.; Yu, X. Spatio-temporal variations in PM leaf deposition: A meta-analysis. Environ. Pollut. 2017, 231, 207-218. [CrossRef]

23. Morar, F.; Iantovics, L.; Gligor, A. Analysis of phytoremediation potential of crop plants in industrial heavy metal contaminated soil in the upper Mures River Basin. J. Environ. Inform. 2018, 31, 1-14.

24. Cai, M.; Xin, Z.; Yu, X. Particulate matter transported from urban greening plants during precipitation events in Beijing, China. Environ. Pollut. 2019, 252, 1648-1658. [CrossRef]

25. Santonastaso, G.; Erto, A.; Bortone, I.; Chianese, S.; Di Nardo, A.; Musmarra, D. Experimental and simulation study of the restoration of a thallium (I)-contaminated aquifer by Permeable Adsorptive Barriers (PABs). Sci. Total Environ. 2018, 630, 62-71. [CrossRef]

26. Raptis, S.; Gasparatos, D.; Economou-Eliopoulos, M.; Petridis, A. Chromium uptake by lettuce as affected by the application of organic matter and $\mathrm{Cr}(\mathrm{VI})$-irrigation water: Implications to the land use and water management. Chemosphere 2018, 210, 597-606. [CrossRef] [PubMed]

27. Liu, B.; Liu, Y.; Zhang, K.; Xie, Y. Classification for soil conservation practices in China. J. Soil Water Conserv. 2013, 27, 80-84.

28. Zhao, J.; Yang, Z.; Govers, G. Soil and water conservation measures reduce soil and water losses in China but not down to background levels: evidence from erosion plot data. Geoderma 2019, 337, 729-741. [CrossRef]

29. Peng, H.; Jia, Y.; Niu, C.; Gong, J.; Hao, C.; Gou, S. Eco-hydrological simulation of soil and water conservation in the Jinghe River Basin in the Loess Plateau, China. J. Hydro-Environ. Res. 2015, 9, 452-464. [CrossRef]

30. Zhou, Y.; Yang, B.; Han, J.; Huang, Y. Robust linear programming and its application to water and environmental decision-making under uncertainty. Sustainability 2019, 11, 33. [CrossRef]

31. Huang, J.; Huang, G.; An, C.; He, Y.; Yao, Y.; Zhang, P.; Shen, J. Performance of ceramic disk filter coated with nano $\mathrm{ZnO}$ for removing Escherichia coli from water in small rural and remote communities of developing regions. Environ. Pollut. 2018, 238, 52-62. [CrossRef]

32. Zhou, Y.; Huang, G.; Baetz, B.W. Multilevel factorial fractional programming for sustainable water resources management. J. Water Resour. Plan. Manag. 2016, 142, 04016063. [CrossRef]

33. Wang, T.; Wu, J.; Kou, X.; Oliver, C.; Mou, P.; Ge, J. Ecologically asynchronous agricultural practice erodes sustainability of the Loess Plateau of China. Ecol. Appl. 2010, 20, 1126-1135. [CrossRef]

34. Li, S.; Di, X.; Wu, D.; Zhang, J. Effects of sewage sludge and nitrogen fertilizer on herbage growth and soil fertility improvement in restoration of the abandoned opencast mining areas in Shanxi, China. Environ. Earth Sci. 2013, 70, 3323-3333. [CrossRef]

35. Shi, H.; Shao, M. Soil and water loss from the Loess Plateau in China. J. Arid. Environ. 2000, 45, 9-20. [CrossRef]

36. Yin, Z.; Gou, J.; Li, Y. Design strategies and soil erosion reduction effect of soil and water conservation measures in hilly area of central Sichuan Basin. Syst. Sci. Compr. Stud. Agric. 2009, 25, 369-374. (In Chinese)

37. Wang, F.; Li, R.; Mu, X.; Yang, X. Characteristics and regional differences of runoff cost of sediment control of conservation measures and their simulation in Weihe River Basin. Sci. Soil Water Conserv. 2004, 2, 12-17. (In Chinese)

38. Change, I.C. The Physical Science Basis. In Contribution of working group $i$ to the fifth assessment report of the Intergovernmental Panel on Climate Change; Cambridge University Press: Cambridge, UK, 2013; Volume 2013, pp. 33-118.

39. Gao, G.Y.; Fu, B.J.; Lü, Y.H.; Liu, Y.; Wang, S.; Zhou, J. Coupling the modified SCS-CN and RUSLE models to simulate hydrological effects of restoring vegetation in the Loess Plateau of China. Hydrol. Earth Syst. Sci. 2012, 16, 2347-2364. [CrossRef]

40. Kendon, E.J.; Rowell, D.P.; Jones, R.G.; Buonomo, E. Robustness of future changes in local precipitation extremes. J. Clim. 2008, 21, 4280-4297. [CrossRef] 
41. Gudmundsson, L.; Bremnes, J.; Haugen, J.; Engen-Skaugen, T. Downscaling RCM precipitation to the station scale using statistical transformations-a comparison of methods. Hydrol. Earth. Syst. Sci. 2012, 16, 3383-3390. [CrossRef]

42. Baltas, E.; Dervos, N.; Mimikou, M. Determination of the SCS initial abstraction ratio in an experimental watershed in Greece. Hydrol. Earth Syst. Sci. Discuss. 2007, 11, 1825-1829. [CrossRef]

43. Mishra, S.K.; Singh, V.P. Validity and extension of the SCS-CN method for computing infiltration and rainfall-excess rates. Hydrol. Process. 2004, 18, 3323-3345. [CrossRef]

44. Wang, H. Estimating watersheds runoff by using improved Runoff Curve Number Model (SCS-CN) on the Loess Plateau of China. Master's Thesis, Beijing Forestry University, Bejing, China, 2016. (In Chinese)

45. Wischmeier, W.H.; Smith, D.D. Predicting rainfall erosion losses: A guide to conservation planning; Science and Education Administration, US Department of Agriculture: Washington, DC, USA, 1978.

46. Renard, K.G.; Foster, G.R.; Weesies, G.A.; Porter, J.P. RUSLE: Revised universal soil erosion equation. J. Soil Water Conserv. 1991, 46, 30-33.

47. Liu, B.; Zhang, K.; Xie, Y. An empirical soil erosion equation. In Proceedings of the 12th International Soil Conservation Organization Conference, Beijing, China, 26-31 May 2002; Tsinghua University Press: Beijing, China, 2002; III, p. 15.

48. Angulo-Martínez, M.; Beguería, S. Estimating rainfall erosivity from daily precipitation records: A comparison among methods using data from the Ebro Basin (NE Spain). J. Hydrol. 2009, 379, 111-121. [CrossRef]

49. Wu, L.; Liu, X.; Ma, X. Spatiotemporal distribution of rainfall erosivity in the Yanhe River watershed of hilly and gully region, Chinese Loess Plateau. Environ. Earth Sci. 2016, 75, 315. [CrossRef]

50. Qin, W.; Guo, Q.; Cao, W.; Yin, Z.; Yan, Q.; Shan, Z.; Zheng, F. A new RUSLE slope length factor and its application to soil erosion assessment in a Loess Plateau watershed. Soil Till. Res. 2018, 182, 10-24. [CrossRef]

51. Zhang, K.; Yu, Y.; Dong, J.; Yang, Q.; Xu, X. Adapting \& testing use of USLE K factor for agricultural soils in China. Agricul. Ecosyst. Environ. 2019, 269, 148-155.

52. Smith, D.D.; Wischmeier, W.H. Factors affecting sheet and rill erosion. Eos Trans. Am. Geophys. Union 1957, 38, 889-896. [CrossRef]

53. Malagó, A.; Vigiak, O.; Bouraoui, F.; Pagliero, L.; Franchini, M. The hillslope length impact on SWAT streamflow prediction in large basins. J. Environ. Inform. 2018, 32, 82-97. [CrossRef]

54. Sun, W.; Shao, Q.; Liu, J.; Zhai, J. Assessing the effects of land use and topography on soil erosion on the Loess Plateau in China. Catena 2014, 121, 151-163. [CrossRef]

55. Kinnell, P. Event soil loss, runoff and the Universal Soil Loss Equation family of models: A review. J. Hydrol. 2010, 385, 384-397. [CrossRef]

56. Renard, K.G.; Foster, G.R. Soil conservation: principles of erosion by water. Dryland. Agric. 1983, 23, $155-176$.

57. Nash, J.; Sutcliffe, J. River forcasting using conceptual models, 1. A discussion of principles. J. Hydrol. 1970, 10, 280-290. [CrossRef]

58. Remesan, R.; Bray, M.; Mathew, J. Application of PCA and clustering methods in input selection of hybrid runoff models. J. Environ. Inform. 2018, 31, 137-152. [CrossRef]

59. Oğuz, I. Rainfall erosivity in north-central anatolia in turkey. Appl. Ecol. Environ. Res. 2019, 17, $2719-2731$.

60. Soulis, K.; Valiantzas, J.; Dercas, N.; Londra, P. Analysis of the runoff generation mechanism for the investigation of the SCS-CN method applicability to a partial area experimental watershed. Hydrol. Earth Syst. Sci. Discuss. 2009, 6, 373-400. [CrossRef]

61. Soulis, K.; Valiantzas, J. SCS-CN parameter determination using rainfall-runoff data in heterogeneous watersheds-the two-CN system approach. Hydrol. Earth Syst. Sci. 2012, 16, 1001-1015. [CrossRef]

62. Xiao, B.; Wang, Q.; Fan, J.; Han, F.; Dai, Q. Application of the SCS-CN model to runoff estimation in a small watershed with high spatial heterogeneity. Pedosphere 2011, 21, 738-749. [CrossRef]

63. Li, C.; Qin, J.; Li, J. Application of computational curve number to precipitation-runoff simulation in a typical watershed in Chinese Loess Plateau. J. Arid. Land. Resour. Environ. 2008, 22, 67-70. (In Chinese)

64. Zhang, K.; Li, S.; Peng, W.; Yu, B. Erodibility of agricultural soils on the Loess Plateau of China. Soil Till. Res. 2004, 76, 157-165. [CrossRef]

65. Wang, B.; Zheng, F.; Guan, Y. Improved USLE- K factor prediction: A case study on water erosion areas in China. Int. Soil Water Conserv. Res. 2016, 4, 168-176. [CrossRef] 
66. Auerswald, K.; Fiener, P.; Martin, W.; Elhaus, D. Use and misuse of the $\mathrm{K}$ factor equation in soil erosion modeling: An alternative equation for determining USLE nomograph soil erodibility values. Catena 2014, 118, 220-225. [CrossRef]

67. Cao, L.; Zhang, K.; Dai, H.; Liang, Y. Modeling interrill erosion on unpaved roads in the Loess Plateau of China. Land Degrad. Dev. 2015, 26, 825-832. [CrossRef]

68. Guo, Q.; Han, Y.; Yang, Y.; Fu, G.; Li, J. Quantifying the impacts of climate change, coal mining and soil and water conservation on streamflow in a coal mining concentrated watershed on the Loess Plateau, China. Water 2019, 11, 1054. [CrossRef]

69. Li, Z.; Liu, W.; Zhang, X.; Zheng, F. Assessing the site-specific impacts of climate change on hydrology, soil erosion and crop yields in the Loess Plateau of China. Clim. Chang. 2011, 105, 223-242. [CrossRef]

70. Azari, M.; Saghafian, B.; Moradi, H.R.; Faramarzi, M. Effectiveness of soil and water conservation practices under climate change in the Gorganroud Basin, Iran. CLEAN - Soil Air Water 2017, 45, 1700288. [CrossRef]

71. Barthes, B.; Roose, E. Aggregate stability as an indicator of soil susceptibility to runoff and erosion; validation at several levels. Catena 2002, 47, 133-149. [CrossRef]

72. Hartanto, H.; Prabhu, R.; Widayat, A.S.; Asdak, C. Factors affecting runoff and soil erosion: plot-level soil loss monitoring for assessing sustainability of forest management. For. Ecol. Manag. 2003, 180, 361-374. [CrossRef]

73. Peng, T.; Wang, S. Effects of land use, land cover and rainfall regimes on the surface runoff and soil loss on karst slopes in southwest China. Catena 2012, 90, 53-62. [CrossRef]

74. Wang, X.; He, K.; Dong, Z. Effects of climate change and human activities on runoff in the Beichuan River Basin in the northeastern Tibetan Plateau, China. Catena 2019, 176, 81-93. [CrossRef]

75. Li, Y.; Liu, C.; Yu, W.; Tian, D.; Bai, P. Response of streamflow to environmental changes: A Budyko-type analysis based on 144 river basins over China. Sci. Total Environ. 2019, 664, 824-833. [CrossRef]

76. Zare, M.; Mohammady, M.; Pradhan, B. Modeling the effect of land use and climate change scenarios on future soil loss rate in Kasilian watershed of northern Iran. Environ. Earth Sci. 2017, 76, 305. [CrossRef]

77. Zheng, F. Effect of vegetation changes on soil erosion on the Loess Plateau. Pedosphere 2006, 16, 420-427. [CrossRef]

78. Zhang, X.; Liu, W.; Li, Z.; Zheng, F. Simulating site-specific impacts of climate change on soil erosion and surface hydrology in southern Loess Plateau of China. Catena 2009, 79, 237-242. [CrossRef]

79. Zhang, X.; Liu, W. Simulating potential response of hydrology, soil erosion, and crop productivity to climate change in Changwu tableland region on the Loess Plateau of China. Agric. For. Meteorol. 2005, 131, 127-142. [CrossRef]

80. Montenegro, A.D.A.; Abrantes, J.; De Lima, J.; Singh, V.; Santos, T. Impact of mulching on soil and water dynamics under intermittent simulated rainfall. Catena 2013, 109, 139-149. [CrossRef]

81. Yan, L. Runoff cost for sediment control of soil and water conservation practices at the plot's scale on the Loess Plateau. Master's Thesis, Northwest A\&F University, Yangling, China, 2008. (In Chinese)

82. Mo, L. Runoff cost of sediment control of soil and water conservation practices with hydrologic methods in Beiluo River Basin. Master's Thesis, Northwest A\&F University, Yangling, China, 2008; pp. 15-18. (In Chinese)

(C) 2020 by the authors. Licensee MDPI, Basel, Switzerland. This article is an open access article distributed under the terms and conditions of the Creative Commons Attribution (CC BY) license (http://creativecommons.org/licenses/by/4.0/). 